\title{
A Remarkable New Genus of Tetraodontiform Fish with Features of Both Balistids and Ostraciids from the Eocene of Turkmenistan
}




\title{
SERIES PUBLICATIONS OF THE SMITHSONIAN INSTITUTION
}

Emphasis upon publication as a means of "diffusing knowledge" was expressed by the first Secretary of the Smithsonian. In his formal plan for the institution, Joseph Henry outlined a program that included the following statement: "It is proposed to publish a series of reports, giving an account of the new discoveries in science, and of the changes made from year to year in all branches of knowledge." This theme of basic research has been adhered to through the years by thousands of titles issued in series publications under the Smithsonian imprint, commencing with Smithsonian Contributions to Knowledge in 1848 and continuing with the following active series:

\author{
Smithsonian Contributions to Anthropology \\ Smithsonian Contributions to Astrophysics \\ Smithsonian Contributions to Botany \\ Smithsonian Contributions to the Earth Sciences \\ Smithsonian Contributions to the Marine Sciences \\ Smithsonian Contributions to Paleobiology \\ Smithsonian Contributions to Zoology \\ Smithsonian Folklife Studies \\ Smithsonian Studies in Air and Space \\ Smithsonian Studies in History and Technology
}

In these series, the Institution publishes small papers and full-scale monographs that report the research and collections of its various museums and bureaux or of professional colleagues in the world of science and scholarship. The publications are distributed by mailing lists to libraries, universities, and similar institutions throughout the world.

Papers or monographs submitted for series publication are received by the Smithsonian Institution Press, subject to its own review for format and style, only through departments of the various Smithsonian museums or bureaux, where the manuscripts are given substantive review. Press requirements for manuscript and art preparation are outlined on the inside back cover.

Robert McC. Adams

Secretary

Smithsonian Institution 


\title{
A Remarkable New Genus of Tetraodontiform Fish with Features of Both Balistids and Ostraciids from the Eocene of Turkmenistan
}

\author{
James C. Tyler \\ and Alexandre F. Bannikov
}

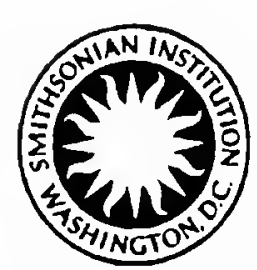

SMITHSONIAN INSTITUTION PRESS

Washington, D.C.

1992 


\begin{abstract}
A B S T R A C T
Tyler, James C., and Alexandre F. Bannikov. A Remarkable New Genus of Tetraodontiform Fish with Features of Both Balistids and Ostraciids from the Eocene of Turkmenistan. Smithsonian Contributions to Paleobiology, number 72, 14 pages, 4 figures, 1 table, 1992.-A new genus and species of tetraodontiform fish, Eospinus daniltshenkoi, is described from the Lower Eocene of Turkmenistan (Danatinsk Formation). It is referred to the Balistoidea because it has three large dorsal-fin spines; the pelvic fin reduced to a rudimentary but prominent structure apparently composed of two partially fused spines at the posterior end of the pelvis; and enlarged scale plates that form an incomplete carapace or loosely articulated armature around much of the body. It differs from all other balistoids in having a long median spine projecting forward from the snout and another spine projecting posteriorly from the middle of each side of the body; lower jaw teeth twice as long as the upper jaw teeth; and in lacking encasing scales around the rudimentary pelvic spine. Eospinus is the first record of a balistoid fish from the Eocene with three dorsal-fin spines and the pelvic spines fused together at the end of the pelvis, as otherwise only occurs in balistids, which are first recorded from the Oligocene.
\end{abstract}

OFFICIAL PUBLICATION DATE is handstamped in a limited number of initial copies and is recorded in the Institution's annual report, Smithsonian Year. SERIES COVER DESIGN: The trilobite Phacops rana Green.

Library of Congress Cataloging-in-Publication Data

Tyler, James C., 1935-

A remarkable new genus of Tetraodontiform fish with features of both Balistids and Ostraciids from the Eocene of Turkmenistan / James C. Tyler and Alexandre F. Bannikov.

p. $\mathrm{cm}$. - (Smithsonian contributions to paleobiology ; no. 72.)

Includes bibliographical references.

1. Eospinus daniltshenkoi-Turkmenistan. 2. Paleontology-Eocene. 3. Paleontology-Turkmenistan. I. Bannikov, A. F. (Aleksandr Fedorovich) 1I. Series.

QE852.T48T95 $1992 \quad 567^{\prime} .5-d c 20 \quad 92-23372$

( The paper used in this publication meets the minimum requirements of the American National Standard for Permanence of Paper for Printed Library Materials Z39.48-1984. 


\section{Contents}

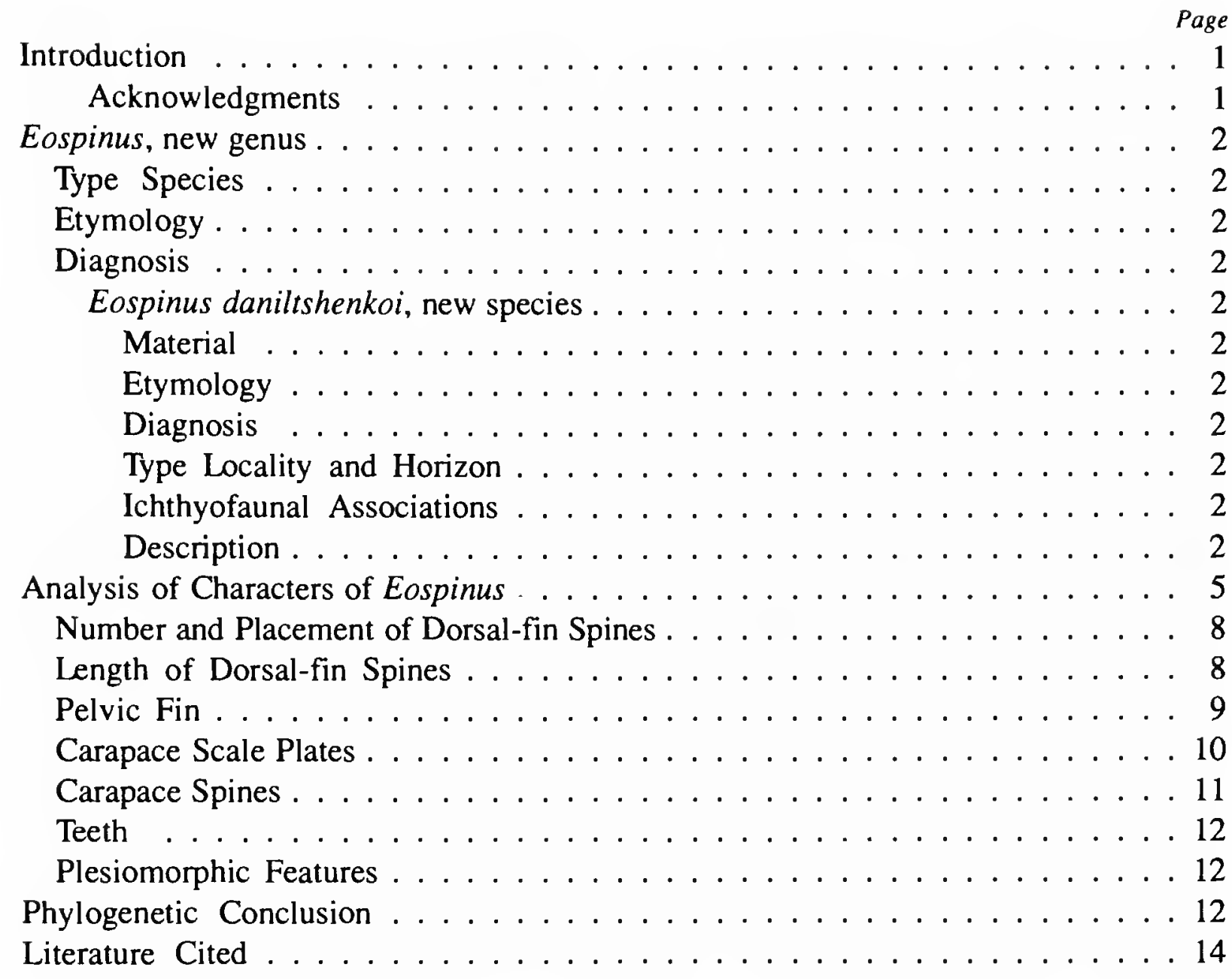





\title{
A Remarkable New Genus of Tetraodontiform Fish with Features of Both Balistids and Ostraciids from the Eocene of Turkmenistan
}

\author{
James C. Tyler \\ and Alexandre F. Bannikov
}

\section{Introduction}

Examination of the specimens of tetraodontiform and possibly related fishes in the collections of the Paleontological Institute in Moscow of the Russian Academy of Sciences has revealed new and unusual members of several families. Among them is a single specimen of a balistoid with specializations that include a long, anteriorly directed median spine on the snout, another spine directed posteriorly on each side of the body, and much larger teeth in the lower jaw than in the upper jaw. It has a covering of enlarged ostraciid-like scale plates forming a partial carapace around the body, three dorsal spines placed over the rear of the skull like balistids but without a locking mechanism, and a rudimentary pelvic fin at the end of the pelvis like balistids but without encasing scales. The uniqueness of this heavily armored species was recognized by P.G. Daniltshenko, the pioneering chronicler of the fossil fish fauna of Russia and adjacent regions, and a sketch he made of it accompanies the specimen in the collection. The specimen has remained undescribed, apparently because of uncertainty about its familial or even ordinal placement.

We place this new form in the Tetraodontiformes because it has a reduced number of caudal-fin rays (12), a reduced number of vertebrae (probably 18-20), and because it lacks anal-fin

James C. Tyler, National Museum of Natural History, Smithsonian Institution, Washington, D.C. 20560. Alexandre F. Bannikov, Paleontological Institute, Russian Academy of Sciences, Profsoyuznaya 123, 117647 Moscow, Russia. spines. We place it in the Balistoidea (sensu Winterbottom, 1974: the balistids, including monacanthids; the ostraciids, including aracanids; and the Eocene spinacanthids) because it has a reduced number ( 3 ) of dorsal-fin spines, a reduced pelvic fin (a rudimentary spine at the end of the pelvis), a reduced number of teeth, which are of heavy conical shape, and enlarged scale plates forming a partial carapace with spiny processes. In several ways the new form is anatomically intermediate between the ostraciid trunkfishes and the clade composed of the balistid triggerfishes and their Eocene spinacanthid sister group. We place the new form incertae sedis in an unresolved trichotomy with the balistids and spinacanthids. This is reflected in the following hierarchical synopsis.

Order TETRAODONTIFORMES Berg (1940), Winterbottom (1974), Tyler (1980)

Suborder TETRAODONTOIDEI (this and other intraordinal categories sensu Winterbottom, 1974)

Superfamily BALISTOIDEA

Family OSTRACliDAE

Incertae sedis: Eospinus

Family SPINACANTHIDAE

Family BALISTIDAE

ACKNOWLEDGMENTS.-We appreciate the support of the Smithsonian Institution's Office of Fellowships and Grants and the Russian Academy of Sciences for travel funds that facilitated the completion of this and other projects involving fossil tetraodontiforms. We thank R. Winterbottom, Royal Ontario Museum, Toronto, and K. Matsuura, National Science 
Museum, Tokyo, for their helpful reviews of the initial manuscript, which was further improved by the preacceptance reviews of C. Patterson, the Natural History Museum (London), J.D. Stewart, Los Angeles County Museum of Natural History, and V.G. Springer, National Museum of Natural History (Smithsonian Institution), and comments by G.D. Johnson and J.T. Williams, National Museum of Natural History. For much help with the cladistic analysis, we are greatly indebted to R. Winterbottom. At the National Museum of Natural History invaluable help was received from R. Clark for photographs, J. Lombardo for typing, and F. Grady for specimen conservation. At the Smithsonian Institution Press we thank J.C. Warren for his careful copy editing and typesetting and D.M. Tyler for preparing the table of characteristics of the taxa.

\section{Eospinus, new genus}

TYPE SPECIES.-Eospinus daniltshenkoi n. sp., by monotypy.

ETYMOLOGY.-Eo for the Eocene age, and spinus for the three large dorsal-fin spines, the carapace spines, and the fused pelvic-fin spine; masculine.

DIAGNOSIS.-Eospinus differs from all other Balistoidea by the presence of a large anteriorly directed median spine on the snout and a posteriorly directed spine on each side of the body, heterodont dentition, absence of a locking mechanism of the three dorsal-fin spines, and absence of encasing scales around the rudimentary pelvic fin at the end of the pelvis.

\section{Eospinus daniltshenkoi, new species}

FIGURES $1-3$

MATERIAL.-Holotype and only known specimen, Paleontological Institute (PIN), Moscow, no. 2179-101, 31.5 mm SL, in part and counterpart, the more complete of the two halves being that with the head to the left, collected 16 October 1959 (Figure 1).

ETYMOLOGY.-The patronym is in honor of P.G. Daniltshenko, now retired from his grand work at the Paleontological Institute in Moscow of describing the fossil fishes of Russia and adjacent regions, who first recognized the uniqueness of this species. We spell the name in the manner he prefers for its Latinization, with a $t s$ rather than a $c$, although in literature references below we use the more commonly cited western spelling Danilchenko.

DIAGNOSIS.-As for the monotypic genus.

TYPE LOCALITY AND HORIZON.-Middle part of Danatinsk Formation, Lower Eocene of southwestern Turkmenistan, close to the village of Uylya-Kushlyuk $\left(38^{\circ} 38^{\prime} \mathrm{N}, 55^{\circ} 48^{\prime} \mathrm{E}\right)$. The Danatinsk Formation is composed of deposits from the Upper Paleocene to the Middle Eocene (Grossheim and Korobkov, 1975) and has a thickness of $200 \mathrm{~m}$ of mottled clays and argillaceous marls. The lower boundary of the Eocene in these deposits is marked by the replacement of foraminifera of the Acarinina subsphaerica Zone complex by those of the Globorotalia subbotinae Zone complex. The fish-bearing layer of brown clays (whose total thickness is about $9 \mathrm{~m}$ ) lies at the base of the lower Eocene portion of the Danatinsk Formation (Solun, 1975). Danilchenko (1968) was in error in supposing that this layer belonged to the lower part of the Danatinsk Formation and therefore was Upper Paleocene in age.

ICHTHYOFAUNAL ASSOCIATIONS.-Up to now 23 species of teleost fishes have been described from the Lower Eocene of the middle part of the Danatinsk Formation (Danilchenko, 1968; Bannikov, 1985). These are mostly species of such pelagic families as the Scombridae, Carangidae, Clupeidae, Menidae, Chanidae, Turkmenidae, Kushlukiidae, and Luvaridae. However, at least one species, the acanthuroid Siganopygaeus rarus Danilchenko, is a member of the inshore, benthic family Siganidae, often associated with coral reefs and adjacent grass flats. We suppose that Eospinus, being heavily armored and probably slow moving, was benthic in habitat and perhaps associated with reefs, as would be expected of a balistoid fish.

DESCRIPTION.-The specimen is only moderately well preserved. The tear-drop shaped body tapers from a deep head to a short, deep, caudal peduncle; the eye is of moderate size in the upper part of the head; the mouth is small and slightly underslung, with distinct teeth of moderate (upper jaw) to large (lower jaw) size; especially prominent features are the long dorsal-fin spines and the median carapace spine on the snout. Very little of the internal structure is exposed because of the covering of enlarged but often fragmented or incomplete scale plates. The part of the parasphenoid under the orbit, the opercular bones, and the posterior edge of the pectoral girdle and postcleithrum are recognizable. There is no indication of a nasal organ. Nothing of diagnostic interest internally is clear, except in a portion of the vertebral column that curves upward over the abdominal region from the level of about the base of the posteriorly directed carapace spine. Somewhat vague contours and vertical grooves in the impression of the column offer faint evidence for the size of the individual centra. Our subjective interpretation is that the vertebrae were relatively large and few in number, consistent with the low number of about $18-20$ as found in triacanthoid and most balistoid tetraodontiforms.

Measurements are standard length (SL) $31.5 \mathrm{~mm}$, greatest depth of body $14.3 \mathrm{~mm}$, approximate diameter of eye $4.0 \mathrm{~mm}$, distance between tip of snout and base of spiny dorsal fin 13.4 $\mathrm{mm}$, length of base of spiny dorsal fin $7.0 \mathrm{~mm}$ (with position of rear edge of recumbent third dorsal spine estimated as though it were erected), distance between posterior end of base of spiny dorsal fin and upper base of caudal fin $16.9 \mathrm{~mm}$, caudal peduncle depth $4.6 \mathrm{~mm}$, approximate length of caudal fin 7.0 $\mathrm{mm}$ (position of rear edge estimated), length of incomplete first dorsal spine $13.0 \mathrm{~mm}$ (based on the thickness and tapering of 


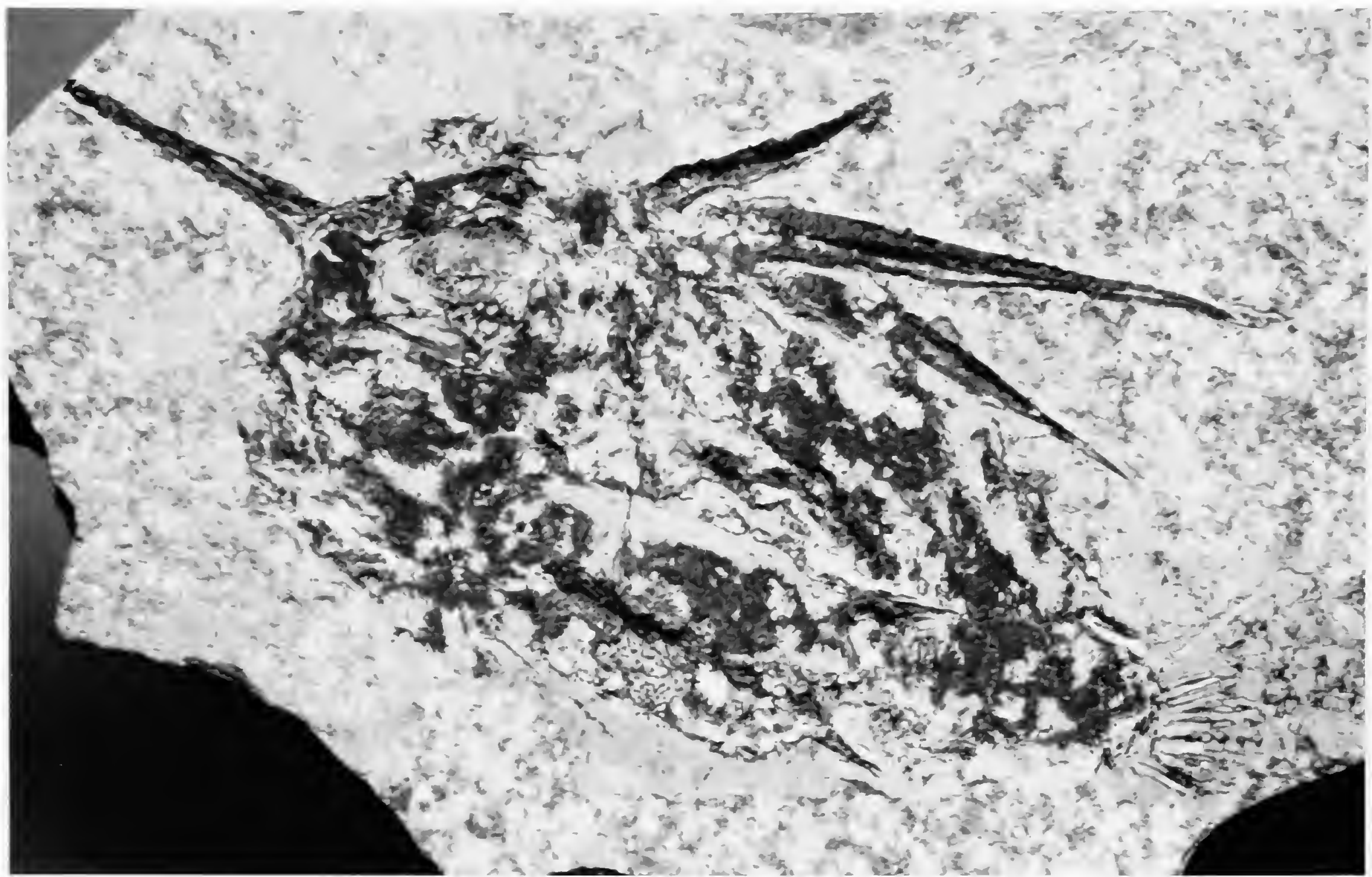

FIGURE 1.-Photograph of the holotype of Eospinus daniltshenkoi, new species, $31.5 \mathrm{~mm}$ SL, PIN 2179-101, Lower Eocene of Turkmenistan.

the preserved portion, the intact length is estimated to be about $23 \mathrm{~mm}$ ), length of second dorsal spine $19.7 \mathrm{~mm}$, length of third dorsal spine $13.1 \mathrm{~mm}$, length of pelvic-fin apparatus protruding from ventral profile of body $4.3 \mathrm{~mm}$, length of incomplete spine projecting anteriorly from snout $8.8 \mathrm{~mm}$ (intact length perhaps about 10 to $12 \mathrm{~mm}$ ), length of longest tooth in lower jaw $1.4 \mathrm{~mm}$, length of longest tooth in upper jaw approximately $0.7 \mathrm{~mm}$.

The body is covered with enlarged scale plates bearing numerous low tubercles or granulations on their surface, with the most central tubercle often larger than the others. Although the peripheral edges of the plates are not well preserved, the plates appear to have varied from irregularly rounded to almost hexagonal. The plates are largest and in closest contact with one another in about the middle of the body, apparently forming an almost continuous covering of armor in the region that supports the posteriorly directed carapace spine and the rudimentary pelvic fin. It is possible that some of the plates were interdigitated, although there is no evidence of the type of more extensive suturing that characterizes the carapace of ostraciids. The scale plates of the head and caudal peduncle are somewhat smaller than those of the middle of the body and are more distantly spaced from one another.
Both the median snout spine and the posterior body spine on each side of the body appear to be processes of the enlarged dermal scale plates with which they are continuous basally; thus, both spines were probably fixed and inflexible. Continuing anteriorly from the base of the posterior body spine is a ridge along the enlarged scale plates, probably forming a crest along the body to below the pectoral-fin base. An even more prominent crest, along what are probably relatively consolidated scale plates, is present ventrolaterally from the region of the base of the rudimentary pelvic fin to the lower region of the cheek. Because this crest terminates at the base of the pelvic fin, we suppose that the pelvic girdle, which is not exposed, is positioned internal to it. The centers of the scale plates along this crest apparently were especially upraised, forming a spinous ventrolateral ridge. The snout spine bears shallow longitudinal grooves and low serrations, while the posterior body spine appears to be similarly but slightly less omamented.

All three dorsal-fin spines are long and robust and at least the first two bear low serrations along the anterior and, especially on the second spine, lateral edges. The distal end of the first dorsal spine is missing, but based on the thickness and degree of tapering of the basal region we estimate that the first spine was only slightly longer ( $73 \% \mathrm{SL})$ than the second (63\% SL), 
while by measurement the length of the third ( $42 \% \mathrm{SL})$ is slightly more than half that of the second. The large rounded base of the second dorsal spine does not appear to make close contact with the posterior edge of the base of the first spine. Therefore, we think it unlikely that the complex locking mechanism of the first spine by the second spine as found in Recent and fossil (as early as the Oligocene) balistids is present. The origin of the spiny dorsal fin is at a level about half way between the eye and the region of the gill slit and pectoral-fin base, and the anterior end of its supporting basal pterygiophores (which cannot be seen because of overlying large scale plates) probably articulated with the posterodorsal surface of the skull.

The base of the caudal fin is preserved and there appear to have been 12 rays, but we cannot determine how many were branched or unbranched because the distal part of the fin is only a faint impression. There are no remains of the pectoral, soft dorsal, or anal fins, and these are shown hypothetically by dashed lines in the reconstruction (Figure 2). We presume that there were no anal-fin spines because if such were present they could be expected to be as easily visible as the dorsal-fin spines, the rudimentary pelvic-fin spine and the carapace spines.

The pelvic fin, although rudimentary, protrudes prominently from the ventral contour of the body. The apparatus as exposed is seen in dorsoventral view (Figure 3) and, therefore, its bilateral symmetry is clear, especially with the clay-like matrix having been carefully removed from along its length. The bony element appears to represent the consolidation of the right and left pelvic spines, as it is a continuous, solid, uninterrupted piece without cross-striations (segmentations) or branching as would be found in a soft ray. The two halves of the spine are fully fused to one another medially except at the distal end. Indentations and irregularities medially along the length of the spine also are evidence of the region of fusion. Strong spiny processes are present along its lateral edges, the more distal of which tend to be retrorse. These spiny processes appear to be fully continuous outgrowths of the spine itself. The base of the pelvic spine abuts against the enlarged scale plate at the posterior end of the ventrolateral ridge along the body armor. At the end of the ventrolateral ridge this scale plate curves medially to meet the base of the spine and presumably overlies the posterior end of the pelvic girdle where the spine would probably be attached. Just above the base of the pelvic spine the body is indented, undoubtedly for the anus. There is no evidence of elongate scales between the anus and the base of the spine, such as those in Recent and fossil balistids that strengthen the somewhat expansible dewlap or fan of skin in

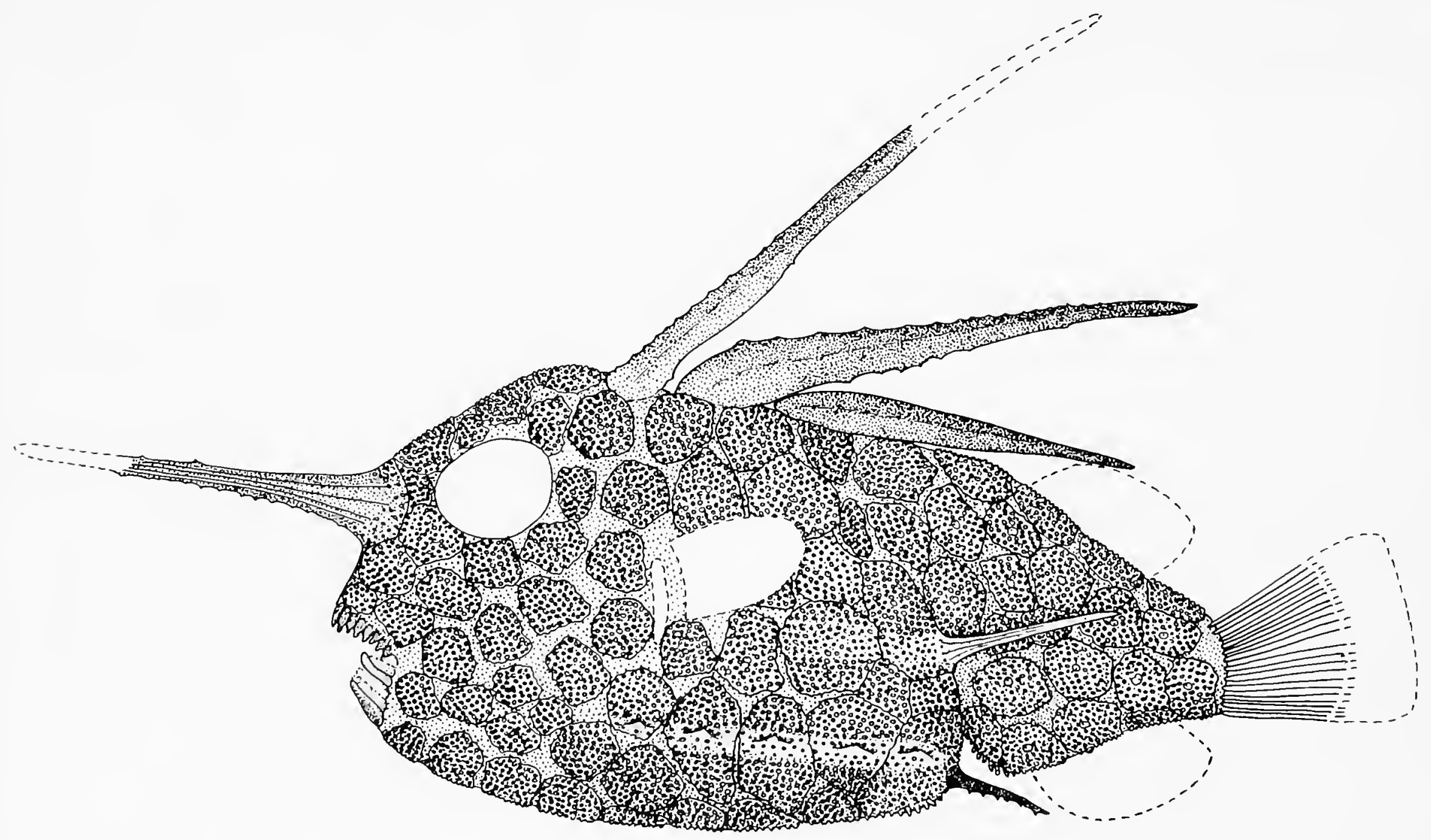

FIGURE 2.-Reconstruction of the holotype of Eospinus daniltshenkoi, new species, $31.5 \mathrm{~mm}$ SL, PIN 2179-101, Lower Eocene of Turkmenistan. 


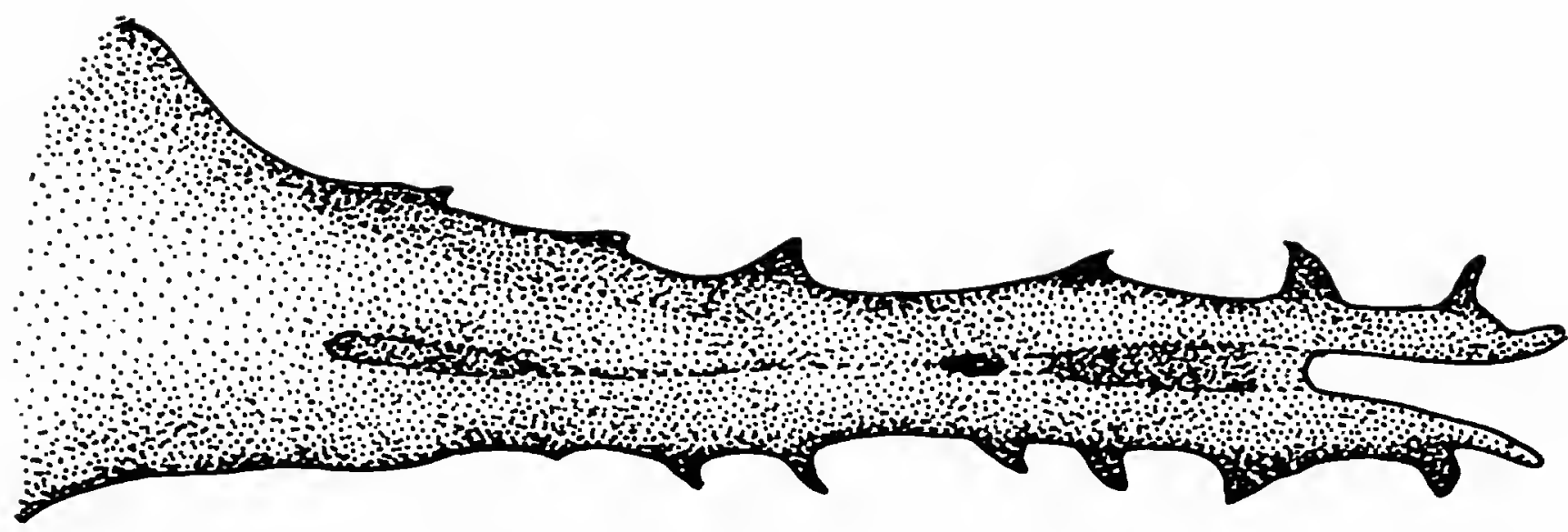

FIGURE 3.-Rudimentary pelvic-fin element of the holotype of Eospinus daniltshenkoi, new species, as seen in dorsoventral view, base of element to left, the pelvic spines from the right and left sides fused together except distally.

this region. Neither is there evidence of a distinct series of scales forming a sheath around the pelvic spine.

The lower jaw teeth are bluntly conical, slightly curved posteriorly toward the distal end, and twice as long as those of the upper jaw. The first four teeth on the side of the jaw are clearly indicated (the second and third by impressions only) and are of about similar length and width, while the few more posterior teeth (probably two) apparently decrease in size (these are not so evident as the first four). The upper jaw teeth are more numerous, with about eight teeth clearly evident in a single row. At least some of the upper jaw teeth, especially those toward the middle of the series, have more constricted distal regions than in the lower jaw, forming blunt nipples. In neither jaw is there evidence of inner series teeth, although such teeth, especially if small, could be hidden behind the large outer teeth.

\section{Analysis of Characters of Eospinus}

For purposes of establishing the systematic position of Eospinus we accept Winterbottom's (1974) higher classification and phylogenetic analysis of the relationships of the Tetraodontiformes, i.e., the Suborder Triacanthoidei (Triacanthodidae and Triacanthidae) is the sister group of the Suborder Tetraodontoidei (all of the other families; see Table 1 for a synopsis of the classification of tetraodontiforms and Figure 4 for their phylogenetic relationships). Within the Tetraodontoidei, the Superfamily Balistoidea (with, among other characters, individual teeth protruding from the jaws; plesiomorphic) is the sister group of the Superfamily Tetraodontoidea (teeth incorporated with jaw bones into a beak; apomorphic). Within the Balistoidea, the Spinacanthidae (two Eocene species) is the sister group of the Balistidae (including monacanthids), while the sister group of the balistid-spinacanthid clade is the Ostraciidae (including aracanids). We follow these categories in the text discussion and in Table 1 summarizing the characters of Eospinus in comparison to all of the other major groups of tetraodontiforms, but in the cladogram (Figure 4) we follow the scheme of Tyler (1980) and recognize the monacanthids and aracanids at the familial level rather than the subfamilial as accorded them in Winterbottom (1974, on which the cladogram is based).

On the basis of 96 osteological and myological autapomorphies, Winterbottom and Tyler (1983) defined the Recent Balistoidea (20 autapomorphies), Balistidae (20), and Ostraciidae (56). Only a few of these are external features that can be seen in both fossil and Recent species. The Spinacanthidae were not treated by Winterbottom and Tyler (1983) and are analyzed here on the basis of the descriptions in Tyler (1980). While the phylogeny of the Recent balistoids as proposed by Winterbottom (1974) and Winterbottom and Tyler (1983) is robust in osteological and myological characters, the placement of the poorly known Eocene spinacanthids (single specimens of each of the two species, with only external features evident) with the balistoids and its sister group relationship with the balistids is based on far fewer characters (elongate ethmoid region, eye high in head, spiny dorsal fin forward on head over eye; Winterbottom, 1974). Even with the limitations from the lack of knowledge of the osteology of spinacanthids we accept these relationships of the balistoids and believe that the few additional features analyzed here for Eospinus will not substantially change them. Obviously, however, as more and more data become available in new taxa like Eospinus with unique combinations of balistoid characters, or from additional specimens of spinacanthids, the previous phylogenetic hypothesis for balistoids should be reanalyzed rather than having the new data appended to it.

On the basis of a phylogenetic analysis of data from early life history stages, Leis (1984) tentatively placed the ostraciids in an unresolved trichotomy with the diodontids and molids as the sister group of the tetraodontids, which in turn were the sister group of the balistids (including monacanthids). The placement of the ostraciids with the tetraodontoids was based on nine characters, but was proposed only with the caution that no data were available for two of the included families, the Triodont- 


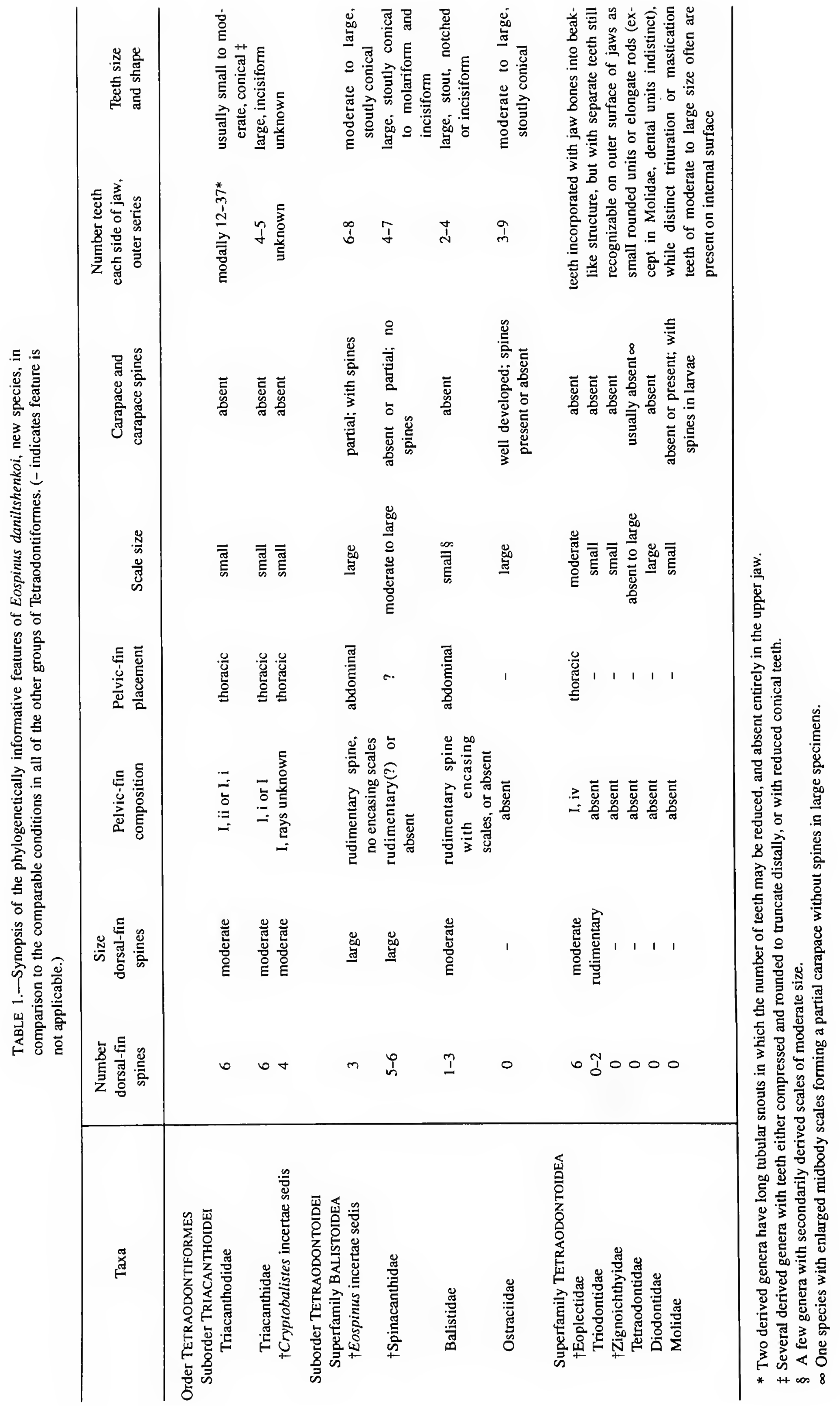



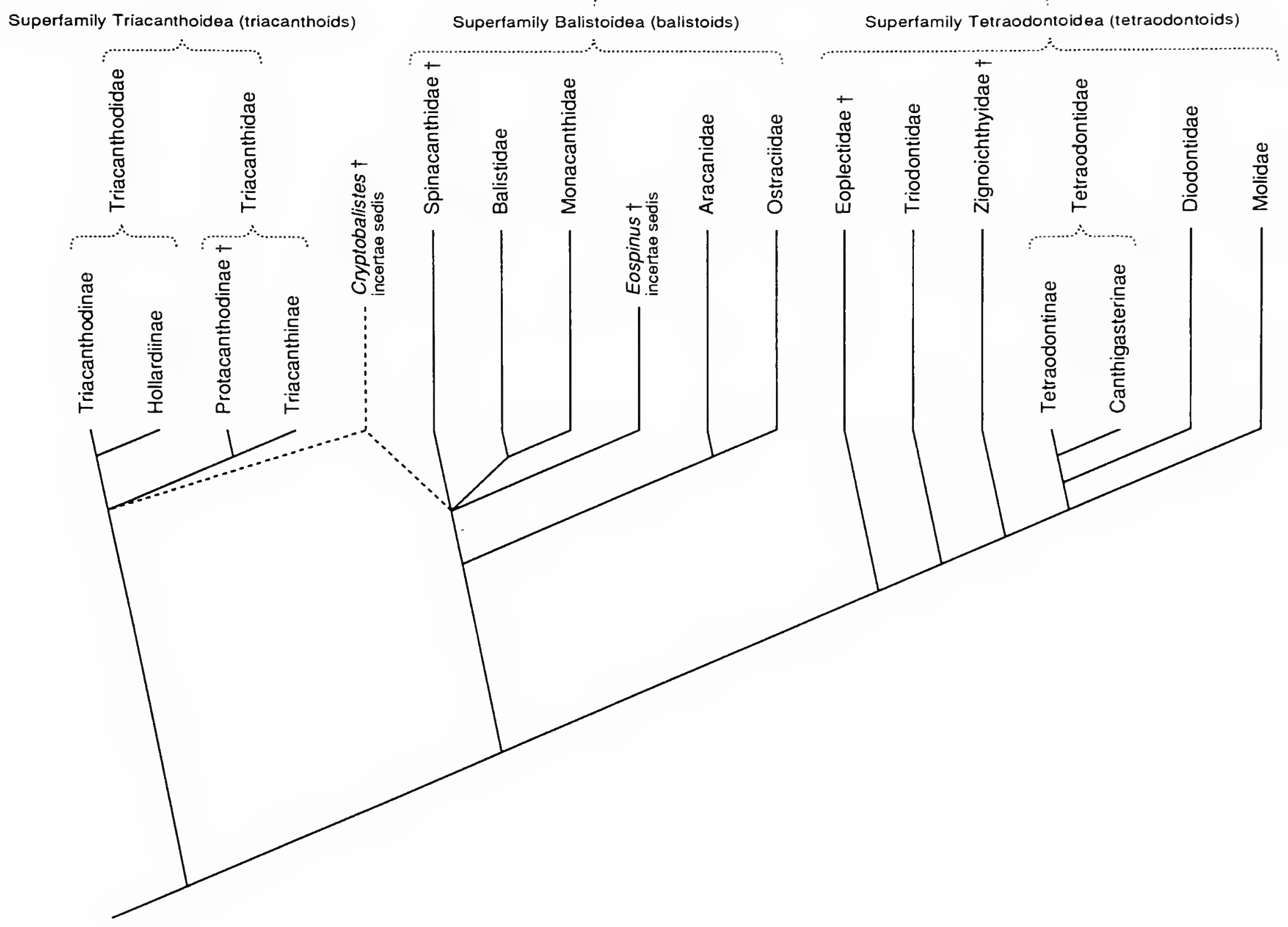

FIGURE 4.-Cladogram of relationships within the Tetraodontiformes, based on Winterbottom (1974), except for changes in the placement of a few fossil groups (Cryptobalistes as incertae sedis rather than a subfamily of Triacanthodidae; Zignoichthyidae as more closely related to Tetraodontidae than to Eoplectidae) and the recognition of families within the balistoids (aracanids, ostraciids, balistids, and monacanthids as families rather than subfamilies).

idae and Aracanidae, the two most morphologically primitive of their respective lines. Although we highly value the evidence offered by early life history stages, in this case we believe that the 20 synapomorphies from the osteology and myology of adults by which Winterbottom and Tyler (1983) defined the balistid-ostraciid clade offer far stronger evidence for the monophyly of that group than do the nine synapomorphies of early life history stages by which Leis (1984) related ostraciids to tetraodontoids, especially as such data were absent for critically important groups of both ostraciids and tetraodontoids.

In Rosen's (1984) proposal of the zeiforms as the primitive sister group of the tetraodontiforms, a rigorous analysis of the inter-relationships of the families of the latter was not intended, and Rosen's placement of the ostraciids in an unresolved trichotomy with the triodontids and other tetraodontoids based on a single synapomorphy (dorsal fins and radials remote from occipital region of skull) and four others, all reductive, linking ostraciids and tetraodontoids (absence of pelvis, ribs, and uncinate process on first epibranchial, and consolidation of the caudal skeleton) obviously is weak in comparison to the evidence presented by Winterbottom and Tyler (1983).

The few known and almost exclusively external characters of Eospinus are compared below with those of spinacanthids, balistids, and ostraciids, and with those of their triacanthoid and tetraodontoid outgroups. The triacanthoids are, in general, the 
most plesiomorphic tetraodontiforms. Among the tetraodontoids we compare Eospinus especially to the Eocene Eoplectus, the most morphologically primitive member of the Superfamily Tetraodontoidea, and to Triodon, the most generalized extant member of the superfamily and the sister group of all of the other extant families of that group.

Number AND PlaCEMENT OF DORSAL-FIN SPINES.Eospinus has three dorsal spines. The plesiomorphic condition for tetraodontiforms is six spines, as found in all Triacanthoidei and in Eoplectus, the most generalized representative of the Tetraodontoidea. Within the Tetraodontoidei, reduction in the number of dorsal spines has taken place independently in the Balistoidea (5-6 spines in Spinacanthidae, 2-3 or rarely 1 in Balistidae, and none in Ostraciidae) and Tetraodontoidea (6 spines in the Eocene Eoplectidae, 1-3 rudimentary spines or none in Triodontidae, and none in the Eocene Zignoichthyidae, Tetraodontidae, Diodontidae, and Molidae).

Winterbottom's (1974) phylogeny of the balistoids indicates that an a posteriori synapomorphy of the ostraciids is the posterior migration of the basal pterygiophore of the spiny dorsal fin toward the origin of the soft dorsal fin and the complete loss of the spiny dorsal fin, with the pterygiophores becoming the prominent supraneural element found just in front of the first basal pterygiophore of the soft dorsal fin in all ostraciids. Conversely, the sister group relationship of balistids and spinacanthids is supported by the anterior migration of the dorsal spines and their pterygiophores to at least the rear of the skull, which condition is apomorphic relative to the position just behind the rear of the skull in the triacanthoid and eoplectid-based outgroups. Spinacanthids retained five or six dorsal spines from the ancestral triacanthoid-eoplectid condition and these spines migrated even further forward onto the top of the skull over the eye and greatly increased in length relative to the moderate length in triacanthoids and eoplectids. The reduction of the number of dorsal spines in balistids to three in balistins and to two (rarely one) in monacanthins is independent of the loss of spines in ostraciids. Balistins retained the position of the spiny dorsal fin and their supports at the rear of the skull, plesiomorphic for the balistidspinacanthid clade, while monacanthins further specialized by the migration of the spines further forward onto the top of the skull, usually to the region of the eye or even in front of the eye. The forward migration of the spiny dorsal fin in monacanthins is here interpreted as independent of that in spinacanthids.

The presence of three dorsal spines in Eospinus relates it to balistids within the spinacanthid-balistid clade, while the origin of the spines at the rear of the skull is the ancestral condition for that clade.

On the basis only of the number of dorsal spines and not of their position (nor of the supraneural in their absence), spinacanthids with five or six spines would be the sister group of both balistids and ostraciids, with three or fewer spines being a synapomorphy for a balistid-ostraciid clade and the complete loss of the dorsal spines a synapomorphy of ostraciids.
It is clear that the position of the spiny dorsal fin was anterior, toward the rear of the skull, in the ancestral balistoid. One could hypothesize that the spines were lost in ostraciids while still in this position and that only then did the basal pterygiophores, having lost their original function of spine support, migrate posteriorly to the origin of the soft dorsal fin to become the supraneural. However, in triodontids, which are the only tetraodontiforms with a rudimentary spiny dorsal fin, the spiny dorsal fin and its pterygiophores have migrated posteriorly to just in front of the soft dorsal fin. Moreover, when the rudimentary spiny dorsal fin is absent (Indian Ocean populations) in the only Recent species, Triodon macropterus Lesson, the basal pterygiophores are entirely comparable to the posteriorly placed supraneural of ostraciids. This analogous positioning of the pterygial supports of the absent spiny dorsal fin in triodontids and ostraciids is in conformity with Winterbottom's (1974) contention of the sister group relationship of spinacanthids and balistids, both of which have anterior migration of the spiny dorsal fin, and the sister group relationship of that clade with the ostraciids, which have posterior migration of the pterygiophores and loss of the spines. This scenario also is consistent with Rosen's (1984) hypothesis of ostraciid relationships.

Eospinus lacks a mechanism by which the second dorsal spine locks the first spine in an erect position. Such a complex specialized locking mechanism is present among tetraodontiforms (and all other fishes) only in the Balistidae (present in all species except for a few highly specialized monacanthins that have lost the second spine). If Eospinus is more closely related to balistids than to other balistoids this would indicate that the reduction in the number of dorsal spines to three in Eospinus and balistids took place in that lineage prior to the development of the locking mechanism in balistids alone, in which case Eospinus would be the sister group of balistids.

LENGTH OF DORSAL-FIN SPINES.-Eospinus has exceptionally long and robust dorsal spines, the first being about $73 \% \mathrm{SL}$ and the second 63\% SL. The plesiomorphic condition for tetraodontiforms is a moderate dorsal-spine length of $17 \%$ 43\% SL as found in the Triacanthoidei (for specimens over 60 $\mathrm{mm}$ SL; smaller specimens with somewhat longer spines, Tyler, 1968). In the only group of Tetraodontoidea with a relatively well-developed spiny dorsal fin, the primitive Eocene Eoplectus (Tyler, 1973b), the spines are incompletely preserved, but from the shape and size of the parts that remain the spines were obviously of only moderate length and probably somewhat shorter than in triacanthoids. In the Balistidae the longest (first) dorsal spine is plesiomorphically moderate in length, usually between $20 \%$ and $30 \%$ SL, and always less than $40 \%$ SL. In the Spinacanthidae the dorsal spines are exceptionally long and strong in both of the monotypic genera, $54 \%$ and 92\% SL in Protobalistum imperiale (Massalongo) and Spinacanthus cuneiformis (de Blainville), respectively. The greatly increased length of the dorsal spines is a synapomorphy 
of the two genera of Spinacanthidae, as is their origin far forward on the head over the small and highly placed eye.

A hypothesis of moderate dorsal-spine length as found in triacanthoids and eoplectids being ancestral for balistoids and increased length acquired by spinacanthids and Eospinus (one step if spinacanthids and Eospinus are sister groups or two steps if balistids and Eospinus are sister groups) is more parsimonious than increased length being ancestral for balistoids and there having been reduction in the length of the spine in balistoids and ostraciids (three steps). Within the balistoids, however, it is equally parsimonious to assume that the spinacanthid-balistid ancestor had increased spine length that was reversed in balistids or that this ancestor had moderate length and that spinacanthids and Eospinus independently acquired increased length if, as evidenced by the number of dorsal spines, Eospinus and balistids are sister groups (two steps in both scenarios).

The evidence from the $73 \%$ SL dorsal-spine length in Eospinus indicates relationship with spinacanthids, while the evidence from the number of spines indicates relationship with balistids. If Eospinus is proposed as the sister group of spinacanthids on the basis of dorsal-spine length, then the number of spines had to be reduced from the ancestral six to three or fewer independently in Eospinus and balistids (two steps). If Eospinus is proposed as the sister group of balistids on the basis of the number of spines, then the size of the spines had to be increased from the ancestral moderate size to large independently in Eospinus and spinacanthids (two steps). None of the other characteristics of Eospinus supports one versus the other of these equally parsimonious alternatives.

PELVIC FIN.-Eospinus has the pelvic fin reduced to a pair of partially fused and relatively large rudimentary spines placed posteriorly at the end of the pelvis. The plesiomorphic condition for tetraodontiforms is a pelvic fin of one spine and two (triacanthoids) to four (eoplectids) rays placed thoracically along the middle of the length of the pelvis below the pectoral fin (condition of pelvis unknown in eoplectids but pelvic fin thoracic). Among the altemate outgroups for tetraodontiforms, most acanthuroids and some zeiforms have a pelvic fin with a spine and five well-developed rays (in some zeiforms up to seven rays if a spine is present or up to 10 rays if the spine is absent; rays reduced to three or four in some specialized acanthuroids). The pelvic fin in zeiforms and acanthuroids is like that of morphologically primitive tetraodontiforms in being placed thoracically along the side of the pelvis, which usually has a prominent posterior process behind the fin; i.e., the fin is never at the extreme posterior end of the pelvis as in balistids.

The pelvic fin of tetraodontiforms has become much reduced, apparently independently, in both lineages of the Tetraodontoidei. In the Tetraodontoidea the pelvic fin is completely lost in all groups except the Eoplectidae, although the Triodontidae retain the pelvis. In the Balistoidea the pelvic fin is either reduced to a complex rudimentary structure at the end of the pelvis in front of the anus or absent altogether. In the Balistidae the pelvic fin rudiment is thought to be the partial fusion product of the pelvic spines from both sides of the body. Except at its distal end, this rudimentary fused spine is surrounded by a series of enlarged encasing scales (in balistins and most monacanthins, while the rudiment and its encasing scales are secondarily further reduced or completely lost in some of the more specialized monacanthins, even though the pelvis is always present: Tyler, 1962; Matsuura, 1979). In the Ostraciidae both the pelvis and pelvic fin are completely lost. In the Eocene Spinacanthidae there is no clear evidence in either of the single specimens of the two species of a pelvic fin or pelvis, and the pelvic fin must be considered to have been either extremely rudimentary or entirely lost.

The spiny structure at the end of the pelvis in Eospinus is less specialized than that of balistids because of its larger or less apomorphically reduced size and its lack of development of the specialized series of encasing scales that surround the rudiment in the more primitive balistids (subsequently lost by some specialized monacanthins). The spiny processes along the lateral edges of the reduced and partially fused pelvic spines in Eospinus also can be interpreted as plesiomorphic relative to the smooth edges of the smaller rudiment in balistids because such spiny processes are present on the pelvic spines of both the more generalized triacanthoid (the triacanthodids) and eoplectid-based outgroups.

In assessing the condition of the pelvic fin in balistoids we presume that there is an ordered, polarized, transformation series from the ancestral condition of a relatively welldeveloped pelvic fin with a spine and at least a few rays (triacanthoids, eoplectids, extraordinal outgroups) to a progressively smaller rudimentary fin before it is entirely lost. In this scenario the pelvic fin became reduced to a large rudiment in the ancestral balistoid, a condition retained by Eospinus, while balistids further reduced the size of the rudiment and ostraciids lost it. Given the frequency of reductive tendencies among many lineages of tetraodontiforms in both pelvic- and dorsal-fin spines, with the numbers and size progressively reduced and then eventually lost, this scenario seems far more reasonable to us than to assume that the ancestral balistoid entirely lost the pelvic fin and it was regained to much different degrees by balistids and Eospinus.

Any further analysis of the pelvic fin in balistoids is severely limited by the unknown condition in spinacanthids. Nevertheless, on the basis only of its relatively large and ornamented rudimentary pelvic fin Eospinus is the sister group of a clade including at least balistids and ostraciids (and spinacanthids if their pelvic fin is no more than a small rudiment, if not absent entirely). The ancestor of such a clade would have had the pelvic fin further reduced to a small rudiment, which was retained by balistids and lost by ostraciids, while the balistids developed a complex specialized series of encasing scales around the rudiment.

Without knowing the condition of the pelvic fin in 
spinacanthids we cannot assess the implications of the placement of the rudimentary pelvic fin at the posterior end of the pelvis just in front of the anus in Eospinus and balistids, versus thoracically placed in all other tetraodontiforms with a pelvic fin (triacanthoids and eoplectids) and in the extraordinal outgroups. If one presumes that the loss of the pelvic fin in ostraciids took place after its migration posteriorly to the end of the pelvis, as was probably the comparable situation with the posterior migration of the spiny dorsal fin associated with its loss, then the position of the pelvic-fin rudiment in Eospinus and balistids is plesiomorphic for balistoids.

We note that if Eospinus had encasing scales around the rudimentary pelvic spine we would accept this as important evidence linking it with the balistids (just as we would if Eospinus had a locking mechanism between the first and second dorsal spines). We believe it unlikely that the loss of the pelvic fin in ostraciids, even if it involved migration to the posterior end of the pelvis, proceeded through a stage in which the rudimentary spine became encased in the specialized series of flexible scale segments found in balistids. This complex apparatus in balistids serves variously to wedge the species into crevices and to flare a dewlap of skin to increase apparent body size in a presumably protective-defensive behavior, and the development of this apparatus has apparently been a key factor in the diversification of the group. We doubt that ostraciids also developed this complex pelvic apparatus only to subsequently lose it before their probable pre-Eocene origins (the ostraciin Eolactoria and the aracaniin Proaracana, both without a pelvis or pelvic fin of any kind, being known from the early Eocene). The balistid pelvic apparatus (and the dorsal-spine locking mechanism) is fully developed in all of the fossil balistids. Balistins are first recorded from the Oligocene by the three species of Balistomorphus from Switzerland and the monotypic Oligobalistes from Russia (Tyler, 1980), while monacanthins are first known from the Pliocene by several species of Aluterus and Cantherhines reported by Sorbini (1987, 1991) from Italy.

CARA PACE SCALE Plates.-Eospinus has enlarged tuberculate scale plates over the entire body, the largest of which are between $12 \%$ and $13 \% \mathrm{SL}$ and tend to form a continuous carapace around the middle of the body, although the plates are not as regularly hexagonal or extensively sutured to one another as in ostraciids. In ostraciids the mostly hexagonal tuberculate scale plates are firmly sutured to one another to form a rigid carapace over most of the body, with scale plates of up to $13 \%$ SL (larger in the Eocene Proaracana, up to $24 \%$ SL).

In spinacanthids one genus, Spinacanthus, has moderately enlarged scales of $4.8 \%$ SL, while the other, Protobalistum, has greatly enlarged scales of $12.3 \% \mathrm{SL}$, and in both cases the scales bear numerous tubercles on the surface, like those of Eospinus and the ostraciids. In Spinacanthus the plates are more or less isolated and only cover a total of about one-fourth of the surface of the body, without much contact between the plates except ventrally. In Protobalistum, however, the scale covering is much more complete, like that of Eospinus. In the anterior half of the body (exclusive of the head) of Protobalis tum many of the plates are distinctly hexagonal and articulate with one another by interdigitations, just as in ostraciids. This is similar to the situation in Eospinus, in which the greatest consolidation of the scale plates and their closest articulation to one another is in the anterior half of the body below the spiny dorsal fin and in front of the pelvic spine and the posteriorly oriented carapace spine.

Scale size in balistids is not well quantified in the literature. Therefore, we made a survey of the size of the scales from the side of the body (i.e., excluding the sometimes larger and more elongate scales at the rear of the abdomen associated with the expansible dewlap) from specimens in the collections of the National Museum of Natural History. Examination of 21 species of balistin triggerfishes (the more generalized of the two groups of balistids), representing nearly all of the genera, shows that the greatest dimension of the scales is usually between $2 \%-3 \%$ (range $1 \%-4 \%$ ) SL, but as much as $5 \%$ SL in Pseudobalistes flavomarginatus (Rüppell) and $7 \% \mathrm{SL}$ in Odonus niger (Rüppell). The thick scales in the aberrant Xenobalistes (enlarged coracoid, postcleithra, and frontal), which has some superficial ostraciid characteristics, are about 3.3\% SL (Matsuura, 1981:194). The scales in the Oligocene genera Balistomorphus and Oligobalistes are only impressions that are difficult to measure, but from their pattern they obviously were small and in the size range of $2 \%-3 \%$ SL like those of most Recent balistins. The scales of monacanthin filefishes tend to be slightly smaller and thinner than those of balistins, and to bear upright spinules, while in some specialized species the scales are almost entirely lost. Thus, the scales in balistids are small, except in a few derived genera of balistins with scales of moderate size, even though the basal scale plate may be thicker in balistins than in triacanthoids.

Among the Tetraodontoidea, the monotypic Eocene Zignoichthys (Zignoichthyidae) has small scales $(0.9 \% \mathrm{SL})$ with upright spinules very similar to those of the Triacanthodidae, the most generalized family of the order, while the monotypic Eocene Eoplectus (Eoplectidae) has moderately enlarged scales (5.8\% SL) with stellate radiations from the base of a central upright spinule. In the Triodontidae, another relatively generalized family of tetraodontoids, the scales are relatively small (3\% SL) except where more elongate in the expansible dewlap of the abdomen. Elsewhere in the Tetraodontoidea the scales often are enlarged as either fixed or erectable spines in most Tetraodontidae and Diodontidae, except where the spines are secondarily reduced or lost in some tetraodontids. However, enlarged plate-like scales similar to those of ostraciids are found in the tetraodontid Ephippion and in the molid Ranzania. The scale plates of Ephippion are up to 9.2\% SL in large adults and form a firmly sutured girdle around the middle of the body (more extensively so than in Eospinus, although the latter has a girdle at a much smaller body size than does Ephippion). The 
scale plates of Ranzania are relatively thin and small, up to $1.2 \% \mathrm{SL}$, but form a complete, if somewhat flexibly sutured, carapace around the entire body. These two genera of different families of the Tetraodontoidea apparently have developed a carapace-like structure independently of one another and of Eospinus, Protobalistum, and the ostraciids among the Balistoidea.

In the triacanthoids, which overall are the most morphologically plesiomorphic group of tetraodontiforms, the scales are relatively small (1\%-3\% SL), with either upright spinules (triacanthodids) or emarginate ridges (triacanthids), including the only Eocene representative, Protacanthodes. Because triacanthoids have small scales, the moderately enlarged plate-like scales of some spinacanthids (Spinacanthus), balistids (Pseudobalistes and Odonus), and eoplectids (Eoplectus) and the greatly enlarged plates of Eospinus, ostraciids, and some spinacanthids (Protobalistum) and tetraodontids (Ephippion) are derived conditions. It seems clear that many of these plate-like enlargements are independent acquisitions (e.g., in tetraodontids and balistids; as are the smaller plate-like scales forming the carapace in the molid Ranzania). Enlarged scales, as either plates or spines, are of such frequent if phylogenetically sporadic occurrence among spinacanthids, eoplectids, ostraciids, tetraodontids, and diodontids, that it also seems clear that scale enlargement is an especially homoplastic feature in tetraodontiforms (as is extreme reduction and loss of scales). Nevertheless, the small scales of triacanthoids must be considered the primitive condition, and enlargement apomorphic.

Given that small scales are primitive for the Triacanthoidei (all species with small scales) and Tetraodontoidea (small scales in morphologically primitive forms like the Eocene Zignoichthys and the Eocene to Recent Triodon, although moderate size scales in the Eocene Eoplectus), it is equally parsimonious ( 3 steps) to assume that the scales in the ancestral balistoids were of either large or small size, but not of moderate size (4 steps). If the balistoid ancestral line had small scales like triacanthoids, then this requires changes for the moderate scale size in Spinacanthus, the large scale size in Protobalistum, and the large scale size of ostraciids. If the balistoid ancestral line had large scales, then this requires changes from the small scale size of triacanthoids, the moderate scale size of Spinacanthus, and the small scale size of nearly all balistids.

Our preferred hypothesis is that the ancestral balistoids had small scales like the triacanthoids and some of the more primitive tetraodontoids, simply because we have no particular reason to believe that a large-scaled balistoid ancestral line is more probable than the proposed small-scaled ancestry. If one accepts small scales as ancestral to balistoids, then the enlargement of scales in Eospinus relates it to either ostraciids or spinacanthids (Protobalistum) in the accepted phylogeny or indicates, contrary to other evidence, that spinacanthids and ostraciids are sister groups to which Eospinus has an unresolved relationship. None of these alternatives are refuted by the possibility that the ancestral balistoids had large scales, in which case the large scales of Eospinus are phyletically uninformative within the balistoids.

In Protobalistum the partial carapace has a ventrolateral ridge, similar to the ridges in this position in most ostraciids and in Eospinus. Just as with scale enlargement, we postulate that the carapace ridge in Protobalistum is an independent acquisition from that in Eospinus and ostraciids. Thus, ridges are interpreted as a common functional aspect of carapace construction irrespective of the phylogenetic origin of the carapace.

CARAPACE SPINES.-Eospinus has a large median carapace spine directed forward from the snout and another fixed spine directed posteriorly from the middle of each side of the body. No such spines are present in spinacanthids and balistids (among the latter neither the flexible quill-like spines found on the side of the body of males of the monacanthin Amanses scopas (Cuvier) nor the enlarged tubercles and spiny processes bome on the scales of the caudal peduncle in many balistins and monacanthins seem homologous to the fixed carapace spines of Eospinus). Among ostraciids only the Eocene Eolactoria has a median, but much shorter, carapace spine on the snout, in the same position as that of Eospinus (the Recent Ostracion rhinorhynchus Bleeker has a blunt, rounded enlargement on the snout, but not a spine). Bilateral carapace spines are present in many ostraciids, either on the supraorbital ridge or along the dorsolateral and ventrolateral ridges of the carapace, but none has a large spine projecting posteriorly from the middle of each side of the body.

While the median snout spines of Eospinus and Eolactoria could be considered a synapomorphy, we discount the significance of this evidence because of the great degree of homoplasy in carapace spines in ostraciids. For example, seemingly identical large carapace spines bilaterally in front of the eyes have been acquired independently by genera in two different phyletic lines of Recent ostraciins, and this is also homoplastic to the occurrence of such preorbital spines in the Oligocene Oligolactoria (Tyler and Gregorova, 1991). Moreover, the numerous spiny scale processes of pelagic larval molids, which apparently act as flotation and defensive devices, include a long anteriorly projecting median snout spine and one projecting posteriorly from each side of the middle of the body (especially in Masturus). These are similar in size and placement to those of Eospinus but they are not associated with a carapace. As molids are one of the most derived groups of tetraodontoids and more closely related to tetraodontids and diodontids than to ostraciids, it is reasonable to assume that the molid snout and body spines have been acquired independently from those of ostraciids. Because there is no other evidence of a close relationship between Eospinus and Eolactoria, we postulate that the snout spines in these two genera (and in larval molids) are homoplastic, and that the presence of carapace spines of any kind in Eospinus is not evidence of relationship with ostraciids. 
TEETH.-Eospinus has a moderate number ( 6 to 8 on each side) of basically conical teeth; those of the lower jaw are stoutly conical and larger than those above, and some of the latter are constricted distally. The plesiomorphic condition for tetraodontiforms is relatively numerous (modally 12 or more on each side), simple, conical teeth without distal constrictions and of equal (small to moderate) size in both jaws. This is the condition found in all species of the Triacanthodidae except for several derived genera with thin, wide, and distally rounded or truncate scraping teeth (sometimes reduced in number or absent in the upper jaw) and/or long tubular snouts. In the Triacanthidae, the more derived of the two families of Triacanthoidei, the teeth are larger, more incisor-like, and reduced in number to four or five on each side in an outer series and one or two in an inner series on each side.

Within the Tetraodontoidei, all Tetraodontoidea have the derived condition of the teeth incorporated with the jaw bones into a specialized beak, while the Balistoidea have teeth that vary from conical to heavy incisors, as follows. Of the two species of Spinacanthidae, Spinacanthus cuneiformis has about seven stoutly conical teeth on each side of the lower jaw (the upper jaw teeth are less visible in the single specimen), some of which taper distally into a strongly constricted blunt nipple. In the other species, Protobalistum imperiale, there are four or five teeth on each side of both jaws, some with straight or rounded distal edges as in incisors or molars, but others with a distinct blunt nipple-like cusp. In the Balistidae the teeth are relatively few, large, compressed, and more-or-less notched and incisor-like, three to four in an outer series on each side, and two or three in an inner series in the upper jaw and two to four in a single series in the lower jaw. In the Ostraciidae the teeth are of moderate size and more or less conical but usually constricted distally, often into a blunt nipple, with between three and nine (usually four to six) in a single series on each side of both jaws. In the two Eocene genera of ostraciids, Eolactoria and Proaracana, the teeth are somewhat larger, heavier, and more notched distally than in the Recent species and bear at least some similarity to the outer teeth of balistids (Tyler, 1973a).

Relative to the simple conical teeth of triacanthodids, the teeth of all three families of balistoids have a derived condition of being enlarged to some degree, less numerous, and in various ways notched, distally constricted, or incisor-like. Within the balistoids, the basically conical, distally constricted teeth of ostraciids and spinacanthids are less derived than are the larger, less numerous, incisor-like teeth in the outer series of balistids. The teeth of Eospinus are more similar to those of spinacanthids and ostraciids than to those of balistids in that they are basically conical and some of them are distally constricted. However, the lower jaw teeth of Eospinus are enlarged, being at least as large as those in the two Eocene genera of ostraciids and not much smaller than those of balistids; and some of the teeth in the spinacanthid Protobalistum are incisor-like.
Thus, there are significant differences in the size and shape of the teeth within each of the families of balistoids, and even within each of the species of the two monotypic genera of spinacanthids, Protobalistum and Spinacanthus. Given this degree of ambiguity, we interpret the teeth of Eospinus as simply relating it to the balistoids but not to a particular family within it. The dentition of Eospinus is best considered as modified for its function in a unique mouth in which the upper jaw teeth are only half as long as and more distally constricted than those in the lower jaw.

PlesiomorPhiC FEaTURES.-Eospinus has 12 principal caudal-fin rays as also found in triacanthoids, spinacanthids, balistids, eoplectids, triodontids, and zignoichthyids rather than the derived condition of 11 or less found in ostraciids, tetraodontids, diodontids, and molids. In Eospinus the eye is of moderate size and placed in about the middle of the upper half of the head, as it is also in triacanthoids and most other tetraodontiforms. The eye is somewhat more elevated in some balistids and in most ostraciids, but these never have the eye so small and highly placed just under the spiny dorsal-fin origin as in spinacanthids, the latter size and placement being a synapomorphy of Spinacanthus and Protobalistum. In Eospinus the soft dorsal and anal fins are not preserved, but based on the space available for them, they obviously were short-based, as in triacanthodids (the most morphologically generalized tetraodontiforms), ostraciids, and most Tetraodontoidea (except moderate in the Eocene Eoplectus and secondarily elongate in Chonerhinos and Xenopterus). In triacanthids (including the Eocene protacanthodins) the soft dorsal fin is secondarily elongate, while in balistids both the soft dorsal and anal fin are apomorphically elongate.

\section{Phylogenetic Conclusion}

The structure of the spiny dorsal fin, pelvic fin, scale plates, and teeth in Eospinus are all phylogenetically informative but some of the evidence conflicts with the accepted phylogeny of the balistoids and leaves the exact relationships of Eospinus uncertain.

The presence of three dorsal spines relates Eospinus to balistids, while the lack of a locking mechanism excludes Eospinus from the balistids as presently defined and places it as the sister group of the balistids. The position of the spiny dorsal fin over the rear of the skull relates Eospinus to spinacanthids and balistids. The increased length of the dorsal spines relates Eospinus to spinacanthids. The presence of a relatively large rudimentary pelvic spine at the end of the pelvis without surrounding encasing scales relates Eospinus to balistoids as this is the presumed ancestral condition of reduction in that clade but, without the condition of the pelvic fin being known in spinacanthids, it is not possible to further use this character to establish relationships within the clade. The shape of the teeth (conical with distal constrictions) relates Eospinus to 
balistoids but not to any particular family because such teeth are plesiomorphic for balistoids. The enlargement of the scale plates into a partial carapace either relates Eospinus to both spinacanthids and ostraciids or is primitive for balistoids.

Although we believe that the evidence presented here abundantly supports our contention that Eospinus is a balistoid, we cannot determine on the basis of its few external characters whether Eospinus is more closely related to balistids or to spinacanthids. Given the tenuousness of the evidence from Eospinus and the weakness of the cladogram at the spinacan- thid-balistid node, we prefer not to make a formal rearrangement of these taxonomic groupings in order to accommodate Eospinus either in an expanded concept of the balistids or as a categorically equivalent sister group of them or of spinacanthids or of both. Rather, we adopt a conservative course and simply place Eospinus incertae sedis with the spinacanthidbalistid clade of balistoids.

We are confident that the exposure of even a few internal osteological features in future specimens of Eospinus will allow for its precise placement among the balistoids. 


\section{Literature Cited}

Bannikov, A.F.

1985. 1skopayemye skumbriyevye SSSR [Fossil Scombrids of the USSR]. Trudy Paleontologicheskogo Instituta AN SSSR, 210:1-111. [In Russian.]

Berg, L.

1940. Classification of Fishes, Both Recent and Fossil. Travaux de l'Institut Zoologique de l'Academie des Sciences de l'URSS, 5:87-517.

Danilchenko, P.G.

1968. Ryby verkhnego paleotsena Turkmenii [Fishes of the Upper Paleocene of Turkmenia]. In D.V. Obruchev, editor, Ocherki po filogenii $i$ sistematike iskopayemykh ryb $i$ beschelyustnykh, pages 113-156. Moscow: Nauka. [In Russian.]

Grossheim, V.A., and I.A. Korobkov, editors

1975. Stratigrafia SSSR: Paleogenovaya sistema [Stratigraphy of the USSR: Paleogene System]. 524 pages. Moscow: Nedra. [In Russian.]

Leis, J.M.

1984. Tetraodontiformes: Relationships. In H.G. Moser, W.J. Richards, D.M. Cohen, M.P. Fahay, A.W. Kendall, Jr., and S.L. Richardson, editors, Ontogeny and Systematics of Fishes. American Society of Ichthyologists and Herpetologists, Special Publication, 1:459-463.

Matsuura, K.

1979. Phylogeny of the Superfamily Balistoidea (Pisces: Tetraodontifor mes). Memoirs of the Faculty of Fisheries, Hokkaido University, 26(1-2):49-169.

1981. Xenobalistes tumidipectoris, a New Genus and Species of Triggerfish (Tetraodontiformes, Balistidae) from the Marianas Islands. Bulletin of the National Science Museum, Tokyo, series A, 7(4):191-200.

Rosen, D.E.

1984. Zeiforms As Primitive Plectognath Fishes. American Museum Novitates, 2782:1-45.

Solun, V.I., editor

1975. Paleogen Turkmenii: Biostratigraficheskoye raschleneniye $i$ korrelatsia [The Paleogene of Turkmenia: Biostratigraphical Dismemberment and Correlation]. 195 pages. Ashkhabad: Ylym. [In Russian.]
Sorbini, L.

1987. Biogeography and Climatology of Pliocene and Messinian Fossil Fish of Eastern-central Italy. Bollettino del Museo Civico di Storia Naturale di Verona, 14:1-85.

1991. The Survival of Pliocene Ichthyofauna of Tethyan Origin in Central Italy. Saito Ho-on Kai Special Publication, 3:459-465.

Tyler, J.C.

1962. The Pelvis and Pelvic Fin of Plectognath Fishes; a Study in Reduction. Proceedings of the Academy of Natural Sciences of Philadelphia, 114(7):207-250.

1968. A Monograph on Plectognath Fishes of the Superfamily Triacanthoidea. Academy of Natural Sciences of Philadelphia, Monograph, 16:1-364.

1973a. A New Species of Boxfish from the Eocene of Monte Bolca, Italy, the First Unquestionable Fossil Record of the Ostraciontidae. Museo Civico di Storia Naturale di Verona, Studi e Ricerche sui Giacimenti Terziari di Bolca, 2:103-127.

1973b. A New Species of Triacanthodid Fish (Plectognathi) from the Eocene of Monte Bolca, Italy, Representing a New Subfamily Ancestral to the Triodontidae and the Other Gymnodonts. Museo Civico di Storia Naturale di Verona, Studi e Ricerche sui Giacimenti Terziari di Bolca, 2:128-156.

1980. Osteology, Phylogeny, and Higher Classification of the Fishes of the Order Plectognathi (Tetraodontiformes). National Oceanic and Atmospheric Administration Technical Report, National Marine Fisheries Service Circular, 434:1-422.

Tyler, J.C., and R. Gregorova

1991. A New Genus and Species of Boxfish (Ostraciidae, Tetraodontiformes) from the Oligocene of Moravia, the Second Fossil Representative of the Family. Smithsonian Contributions to Paleobiology, 71:1-20.

Winterbottom, $\mathrm{R}$.

1974. The Familial Phylogeny of the Tetraodontiformes (Acanthopterygii: Pisces) as Evidenced by Their Comparative Myology. Smithsonian Contributions to Zoology, 155:1-201.

Winterbottom, R., and J.C. Tyler

1983. Phylogenetic Relationships of Aracanin Genera of Boxfishes (Ostraciidae: Tetraodontiformes). Copeia, 1983(4):902-915. 




\section{REQUIREMENTS FOR SMITHSONIAN SERIES PUBLICATION}

Manuscripts intended for series publication receive substantive review (conducted by their originating Smithsonian museums or offices) and are submitted to the Smithsonian Institution Press with Form SI-36, which must show the approval of the appropriate authority designated by the sponsoring organizational unit. Requests for special treatment-use of color, foldouts, case-bound covers, etc.--require, on the same form, the added approval of the sponsoring authority.

Review of manuscripts and art by the Press for requirements of series format and style, completeness and clarity of copy, and arrangement of all material, as outlined below, will govern, within the judgment of the Press, acceptance or rejection of manuscripts and art.

Copy must be prepared on typewriter or word processor, double-spaced, on one side of standard white bond paper (not erasable), with 11/4" margins, submitted as ribbon copy (not carbon or xerox), in loose sheets (not stapled or bound), and accompanied by original art. Minimum acceptable length is 30 pages.

Front matter (preceding the text) should include: title page with only title and author and no other information, abstract page with author, title, series, etc., following the established format; table of contents with indents reflecting the hierarchy of heads in the paper; also, foreword and/or preface, if appropriate.

First page of text should carry the title and author at the top of the page; second page should have only the author's name and professional mailing address, to be used as an unnumbered footnote on the first page of printed text.

Center heads of whatever level should be typed with initial caps of major words, with extra space above and below the head, but no other preparation (such as all caps or underline, except for the underline necessary for generic and specific epithets). Run-in paragraph heads should use period/dashes or colons as necessary.

Tabulations within text (lists of data, often in parallel columns) can be typed on the text page where they occur, but they should not contain rules or numbered table captions.

Formal tables (numbered, with captions, boxheads, stubs, rules) should be submitted as carefully typed, double-spaced copy separate from the text; they will be typeset unless otherwise requested. If camera-copy use is anticipated, do not draw rules on manuscript copy.

Taxonomic keys in natural history papers should use the aligned-couplet form for zoology and may use the multi-level indent form for botany. If cross referencing is required between key and text, do not include page references within the key, but number the keyed-out taxa, using the same numbers with their corresponding heads in the text.

Synonymy in zoology must use the short form (taxon, author, year:page), with full reference at the end of the paper under "Literature Cited," For botany, the long form (taxon, author, abbreviated journal or book title, volume, page, year, with no reference in "Literature Cited") is optional.

Text-reference system (author, year:page used within the text, with full citation in "Literature Cited" at the end of the text) must be used in place of bibliographic footnotes in all Contributions Series and is strongly recommended in the Studies Series: "(Jones, 1910:122)" or ". . Jones (1910:122)." If bibliographic footnotes are required, use the short form (author, brief title, page) with the full citation in the bibliography.

Footnotes, when few in number, whether annotative or bibliographic, should be typed on separate sheets and inserted immediately after the text pages on which the references occur. Extensive notes must be gathered together and placed at the end of the text in a notes section.

Bibliography, depending upon use, is termed "Literature Cited," "References," or "Bibliography." Spell out titles of books, articles, journals, and monographic series. For book and article titles use sentence-style capitalization according to the rules of the language employed (exception: capitalize all major words in English). For journal and series titles, capitalize the initial word and all subsequent words except articles, conjunctions, and prepositions. Transliterate languages that use a non-Poman alphabet according to the Library of Congress system. Underline (for italics) titles of journals and series and titles of books that are not part of a series. Use the parentheses/colon system for volume (number): pagination: "10(2):5-9." For alignment and arrangement of elements, follow the format of recent publications in the series for which the manuscript is intended. Guidelines for prepaning bibliography may be secured from Series Section, SI Press.

Legends for illustrations must be submitted at the end of the manuscript, with as many legends typed, double-spaced, to a page as convenient.

Illustrations must be submitted as original art (not copies) accompanying, but separate from, the manuscript. Guidelines for preparing art may be secured from Series Section, SI Press. All types of illustrations (photographs, line drawings, maps, etc.) may be intermixed throughout the printed text. They should be termed Figures and should be numbered consecutively as they will appear in the monograph. If several illustrations are treated as components of a single composite figure, they should be designated by lowercase italic letters on the illustration; also, in the legend and in text references the italic letters (underlined in copy) should be used: "Figure 9b." Illustrations that are intended to follow the printed text may be termed Plates, and any components should be similarly lettered and referenced: "Plate 9 b." Keys to any symbols within an illustration should appear on the art rather than in the legend.

Some points of style: Do not use periods after such abbreviations as "mm, ft, USNM, NNE." Spell out numbers "one" through "nine" in expository text, but use digits in all other cases if possible. Use of the metric system of measurement is preferable; where use of the English system is unavoidable, supply metric equivalents in parentheses. Use the decimal system for precise measurements and relationships, common fractions for approximations. Use day/month/year sequence for dates: "9 April 1976." For months in tabular listings or data sections, use three-letter abbreviations with no periods: "Jan, Mar, Jun," etc. Omit space between initials of a personal name: "J.B. Jones."

Arrange and paginate sequentially every sheet of manuscript in the following order: (1) title page, (2) abstract, (3) contents, (4) foreword and/or preface, (5) text, (6) appendixes, (7) notes section, (8) glossary, (9) bibliography, (10) legends, (11) tables. Index copy may be submitted at page proof stage, but plans for an index should be indicated when manuscript is submitted. 


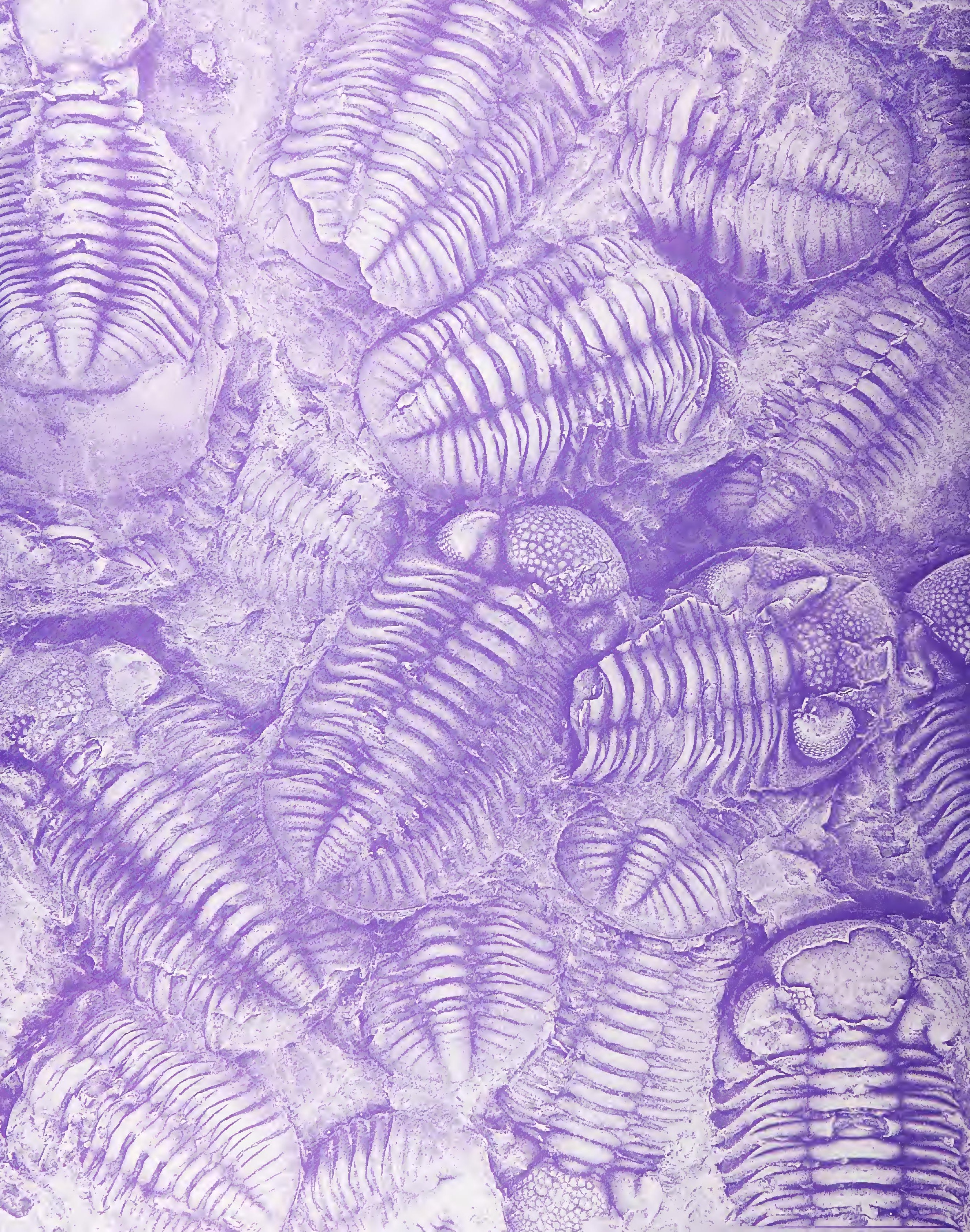

